\title{
Effect of Thermal Cycling on the Strength and Texture of Concrete for Nuclear Safety Structures
}

\author{
Š. Hošková, O. Kapičková, K. Trtík, F. Vodák
}

The effect of thermal cycling (freezing and thawing) on the texture and strength of two types of concrete is studied:

1. Concrete used for a containment structure at NPP Temelin (Czech Republic)-so-called TEMELÍN concrete.

2. Highly resistant PENLY concrete, which was used as a standard because of its high quality, proved by the research carried out in a European Commission project.

The results for the two samples of concrete are compared.

Keywords: Concrete, thermal cycling, texture, strength, porosity.

\section{Introduction}

The mechanical and physical properties of concrete deteriorate during the ageing process. Climatic conditions play a major role in this process [1]. The texture of concrete is not constant in time. When it is in a water saturated condition and subjected to freezing and thawing cycles, concrete is susceptible to damage caused by hydraulic pressure generated in the capillary cavities of the cement paste as water freezes. Therefore, the compressive strength of concrete is definitely determined by modifications of its structure.

Changes in the strength of concrete under the impact of cycles is studied in this article. Changes in porous cement paste texture are also investigated.

\section{Material composition}

All studies were carried out on two concrete types: concrete from the Czech Republic, used for a containment structure at NPP TEMELÍN (T), and high-resistance PENLY concrete (P) (France). The composition of the concrete mix-

Table 1: Composition of the concrete mixtures for production of $1 \mathrm{~m}^{3}$ of fresh concrete

\begin{tabular}{|c|c|c|}
\hline COMPONENT & PENLY & TEMELÍN \\
\hline Cement & $290 \mathrm{~kg}(\mathrm{CPA})$ & $499 \mathrm{~kg}(42.5 \mathrm{R})$ \\
\hline Water & $131 \mathrm{~kg}$ & $215 \mathrm{~kg}$ \\
\hline $\begin{array}{c}\text { Silica fume } \\
\text { (Anglefort) }\end{array}$ & $30 \mathrm{~kg}$ & - \\
\hline $\begin{array}{c}\text { Calcareous filler } \\
\text { (Piketty) }\end{array}$ & $105 \mathrm{~kg}$ & - \\
\hline $\begin{array}{c}\text { Superplasticizer } \\
\text { (Resino CT) }\end{array}$ & $10.62 \mathrm{~kg}$ & - \\
\hline \begin{tabular}{c} 
Retarder (Chrytard) \\
\hline $\begin{array}{c}\text { Plasticizer: } \\
\text { Ligoplast SF }\end{array}$
\end{tabular} & $1.7 \mathrm{~kg}$ & - \\
\hline $\begin{array}{c}\text { Aggregates } \\
\text { river gravel } \\
\text { crushed agg. } \\
\text { crushed agg. }\end{array}$ & $\begin{array}{c}831 \mathrm{~kg} \quad 0-5 \mathrm{~mm} \\
287 \mathrm{~kg} \quad 5-12.5 \mathrm{~mm}\end{array}$ & $\begin{array}{l}710 \mathrm{~kg} \quad 0-4 \mathrm{~mm} \\
752 \mathrm{~kg} 12.5-25 \mathrm{~mm} \quad 8-16 \mathrm{~mm}\end{array}$ \\
$530 \mathrm{~kg} 16-22 \mathrm{~mm}$ \\
\hline
\end{tabular}

tures for production of $1 \mathrm{~m}^{3}$ of ready material is shown in Table 1 . The chemical composition of the cements ( $\%$ by weight) is shown in Table 2.

Table 2: Quantitative composition of cements (\% by weight)

\begin{tabular}{|c|c|c|}
\hline Sample & CP 52.5 France & CEM I 42.5 Mokra \\
\hline \multicolumn{3}{|c|}{ Phase clinker composition } \\
\hline $\mathrm{C}_{3} \mathrm{~S}$ & 53.7 & 68.5 \\
\hline $\mathrm{C}_{2} \mathrm{~S}$ & 26.7 & 11.6 \\
\hline $\mathrm{C}_{3} \mathrm{~A}$ & 4.4 & 7.4 \\
\hline $\mathrm{C}_{4} \mathrm{AF}$ & 14.8 & 11.5 \\
\hline $\mathrm{C}_{\text {free }}$ & 0.4 & 1.0 \\
\hline Total & 100.0 & 100.0 \\
\hline $\mathrm{C}_{3} \mathrm{~S}_{\mathrm{eq}}$ & 55.4 & 72.7 \\
\hline $\mathrm{C}_{\mathrm{g}} \mathrm{S}_{\mathrm{eq}}$ & 25.4 & 8.4 \\
\hline \multicolumn{3}{|c|}{ Components fraction in cement } \\
\hline Clinker & 97.0 & 95.0 \\
\hline Gypsum & 2.9 & 3.5 \\
\hline Fly ash & 0.1 & 1.3 \\
\hline Slag & Trace & 0.2 \\
\hline Total & 100.0 & 100.1 \\
\hline Sample & CP 52.5 France & CEM I 42.5 Mokra \\
\hline \multicolumn{3}{|c|}{ Components fraction without gypsum } \\
\hline Clinker & 99.9 & 98.4 \\
\hline Fly ash & 0.1 & 1.4 \\
\hline Slag & Trace & 0.2 \\
\hline Total & 100.0 & 100.0 \\
\hline
\end{tabular}

Both types of concrete are formed on the basis of Portland cement and have approximately the same water cement ratio (PENLY - 0.43 and TEMELÍN - 0.45). These are the only similar factors: TEMELÍN concrete belongs to class B 40, while PENLY concrete is prepared as so-called high-resistance concrete (the uniaxial compression strength is higher than $60 \mathrm{MPa})$ [3]. 


\section{Experimental details}

An artificial ageing process was simulated by thermal cycling. The samples were completely saturated with water and were cooled down to a temperature of $-20{ }^{\circ} \mathrm{C}$. They were then warmed up to $+25^{\circ} \mathrm{C}$ in a HEREAUS HC 4020 conditioning chamber. The total time of one temperature cycle was 6 hours. Relative humidity of $95 \%$ was maintained.

A test of the compressive strength of the concrete was performed on the second fragment of the original beam. The $[100 \times 100] \mathrm{mm}$ steel square plates, whose edges fitted with the face of the original beam, were placed on the body of the specimen. The test was performed in accordance with Czech National Standard ČSN 731318 .

The pore- and cracks- distribution curve of the cement paste and the total specific volume of the pores were determined by mercury porosimetry. The porosimetric measurements were carried out at the Institute of Chemical Process of the Academy of Sciences of the Czech Republic.

Table 3 shows the results of measurements of the compressive strength and volume of pores in dependence on the numbers of cycles for PENLY and TEMELÍN concrete. A graphical depiction is presented in Figs. 1 and 2. The compressive strength and the specific volume are presented here in percentages, where the value of $100 \%$ corresponds to a non-cycled sample (age 28 days).

Table 3: Strength and volume of pores in dependence on the number of cycles

\begin{tabular}{|c|c|c|}
\hline $\begin{array}{c}\text { Number of } \\
\text { cycles }\end{array}$ & $\begin{array}{c}\text { Strength } \\
{[\mathrm{MPa}]}\end{array}$ & $\begin{array}{c}\text { Specific volume of pores } \\
{\left[\mathrm{mm}^{3} / \mathrm{g}\right]}\end{array}$ \\
\hline PENLY & \multicolumn{2}{|c|}{} \\
\hline 0 & 64.4 & 35.1 \\
\hline 100 & 74.4 & 33.9 \\
\hline 200 & 65.2 & 37.7 \\
\hline 300 & 53.8 & 39.2 \\
\hline TEMELÍN & & \\
\hline 0 & 52.3 & 38.5 \\
\hline 100 & 57.7 & 31.0 \\
\hline 200 & 56.5 & 49.9 \\
\hline 400 & 47.9 & 57.2 \\
\hline
\end{tabular}

Table 4 relates the age of the samples and the number of climatic cycles.

Table 4: Age of samples and the number of climatic cycles

\begin{tabular}{|c|c|c|}
\cline { 2 - 3 } \multicolumn{1}{c|}{} & \multicolumn{2}{c|}{ Age of concrete (days) } \\
\hline $\begin{array}{c}\text { NUMBER OF } \\
\text { CYCLES }\end{array}$ & PENLY & TEMELÍN \\
\hline 0 & 28 & 28 \\
\hline 100 & 84 & 86 \\
\hline 200 & 184 & 186 \\
\hline 300 & 281 & - \\
\hline 400 & - & 304 \\
\hline
\end{tabular}

\section{Discussion}

Our experimental results in Fig. 1, 2 show that the behaviour of both types of concrete (TEMELÍN, PENLY) is analogous in the investigated parameters. Also, Fig. 1 shows that the changes in compressive strength during thermal

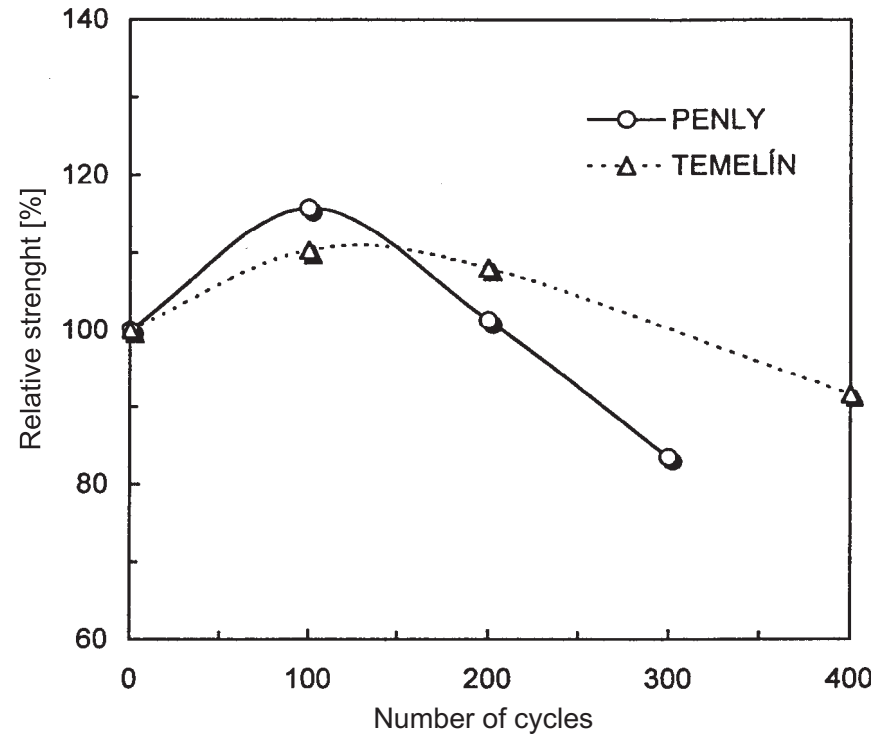

Fig. 1: Dependence of the relative strength on the number of cycles

cycling are lower in the case of TEMELÍN. A decrease of compressive strength brings about $8.4 \%$ of the initial value in the case of TEMELÍN (after 400 cycles), and about $16.5 \%$ in the case of PENLY already after 300 cycles. Additional loading above 300 cycles results in the destruction of the PENLY samples.

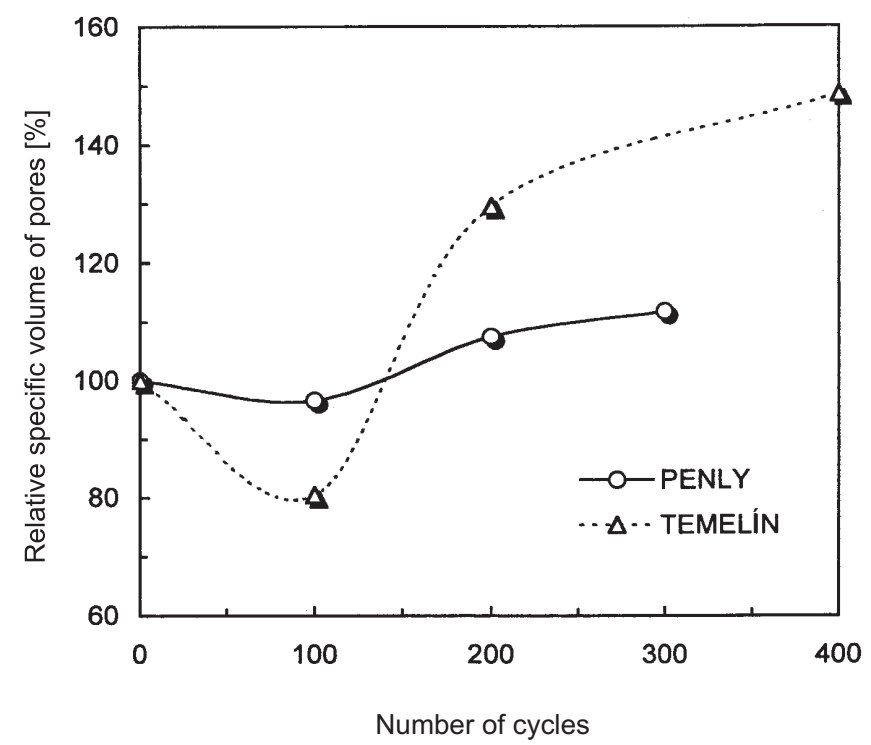

Fig. 2: Dependence of the relative specific volume of pores on the number of cycles

Both of the dependencies (Fig. 1, 2) present extremes after about 100 climatic cycles: maximum values for compressive strength (Fig. 1) and minimum values for a specific volume of pores (Fig. 2). It is a known fact that in solids there is an inverse relationship between porosity and strength [2], [3]. It should be noted that the measurement of compressive 
strength was carried out on samples of concrete, but the specific volume of pores were studied on samples of cement paste. However, in concrete the porosity of the cement paste usually determines the strength characteristic. Obviously, our results are in accordance with the assumed theoretical dependence between porosity and strength.

After about 100 climatic cycles the strength in both materials increased and the volume of pores decreased. This result probably relates to the fact that during the first cycles the porous structure of the samples "matured". Under ideal moisture conditions in the climatic chamber hydration is further in progress and causes a decrease in the volume of the pores and a refining of the porous structure. This process evidently prevails over cracking of the porous structure as a consequence of the temperature cycling. The change in the development of the porous structure causes the corresponding behaviour of the strength of the two samples (TEMELÍN, PENLY).

\section{Aknowledgements}

This work was supported by the MŠMT ČR (contract No. J04-098:210000004) and the Grant Agency of the Czech Republic (grant No. 103/99/0248).

\section{References}

[1] Pachner, J. et al.: Concrete containment buildings. IAEA TECDOC - 1025, Vienna, IAEA, 1998
[2] Mehta, P. K. - Mouteiro: Concrete. New Jersey, Prentice Hall, 1993

[3] Schneider, U.: Behaviour of concrete at high temperatures. Deutscher Ausschuss für Stahlbeton, Berlin, Verlag Ernst \& Sohn, 1982

RNDr. Šárka Hošková

Department of Physics

phone: +420224354695

e-mail: hoskova@fsv.cvut.cz

RNDr. Olga Kapičková, CSc.

Department of Physics

phone: +420224354696

e-mail: kapickov@fsv.cvut.cz

Doc. Ing. Karel Trtík, CSc.

Department of Concrete Structures and Bridges phone: +420224354626

e-mail: trtik@fsv.cvut.cz

Prof. František Vodák, DrSc.

Department of Physics

phone: +420224353886

e-mail:vodak@fsv.cvut.cz

Czech Technical University in Prague

Faculty of Civil Engineering

Thákurova 7, 16629 Praha 6, Czech Republic 